\title{
KERIPIK SALAK VACUUM FRYING SEBAGAI ALTERNATIF PENGEMBANGAN PRODUK INOVATIF DI DAERAH AGROKLIMAT BANGKALAN MADURA
}

\section{(VACUUM FRYING SALAK CHIPS AS AN ALTERNATIVE DEVELOPMENT OF INNOVATIVE PRODUCTS IN THE AGROCLIMATE AREA BANGKALAN MADURA)}

\author{
Dedin F Rosida, ${ }^{1}$ B Syehan ${ }^{2}$, Dedid Cahya Happyanto ${ }^{3}$, FT Anggraeni ${ }^{4}$, Nur \\ Hapsari $^{5}$ \\ ${ }^{1,2)}$ Program Studi Teknologi Pangan, Fakultas Teknik Universitas Pembangunan \\ Nasional Veteran Jawa Timur, ${ }^{3)}$ Jurusan Elektronika, Politeknik Elektronika Negeri \\ Surabaya, ${ }^{4)}$ Program Studi Informatika, ${ }^{5)}$ Program Studi Teknik Kimia, Fakultas
} Teknik Universitas Pembangunan Nasional Veteran Jawa Timur e-mail: dedin.tp@upnjatim.ac.id

\begin{abstract}
Efforts to maintain the quality and storage of fruit is to process it into dry food. Fruit processing into chips needs to be technologically supported so that the quality of chips produced can be accepted by consumers. One way to produce healthy food without changing its original shape is to use vacuum frying technology. Using a vacuum frying, the result had better, the chips were not burnt, keep bright as the original colour and the vitamin content was not damaged. In this program produced salak chips with the characteristics of maximum moisture content of $9.9 \%$ ash content of $3.1 \%$, fat content of $24.1 \%$, during storage for up to 6 weeks. The composition of salak chips was better with aluminium foil packaging than plastic. Salak chips produced still be the quality standards of fruit chips according to SNI 01-4306-1996, namely maximum moisture content of $22 \%$, ash of $3 \%$ and fat of $25 \%$.
\end{abstract}

Keywords: quality standard, salak fruit, technology, vacuum frying

abstrak

Upaya mempertahankan mutu dan daya simpan buah adalah mengolahnya menjadi makanan kering. Pengolahan buah menjadi keripik perlu dukungan teknologi sehingga kualitas keripik yang dihasilkan dapat diterima konsumen. Salah satu cara untuk menghasilkan makanan sehat tanpa mengubah bentuk aslinya adalah dengan menggunakan teknologi penggorengan vakum. Penggunakan pengorengan vacuum, hasilnya akan lebih bagus, keripik tidak gosong, tetap cerah seperti warna aslinya dan kandungan vitamin dari buah olahan tidak rusak. Pada kegiatan pengabdian masyarakat ini dihasilkan keripik buah salak dengan karakteristik kadar air maksimal 9.9\% kadar abu sebesar $12.5 \%$ kadar lemak $24.1 \%$ selama penyimpanan sampai 6 minggu. Komposisi keripik salak ini lebih baik dengan kemasan aluminium foil daripada kemasan plastik. Keripik salak yang dihasilkan masih memenuhi Standar mutu keripik buah menurut SNI 01-4306-1996, yaitu kadar air maksimal 22\%, kadar abu maksimal 3\% dan kadar lemak maksimal $25 \%$.

Kata Kunci: buah salak, standar mutu, teknologi, vacuum frying 


\section{PENDAHULUAN}

Buah Salak adalah buah lokal khas Indonesia asalnya dari Pulau Jawa dan Sumatera. Kini sebarannya bisa ditemukan hampir diseluruh wilayah Indonesia. Kabupaten Bangkalan merupakan salah satu daerah yang memiliki potensi cukup besar dalam sektor pertanian khususnya salak. Berdasarkan survey pada lahan petani Salak, di Pulau Madura khususnya desa Kramat Kabupaten Bangkalan memiliki dua belas jenis salak yang didasarkan pada ciri morfologi buah. Masyarakat menyebut ke dua belas jenis salak tersebut adalah salak air, salak se nase', salak aren, salak pandan, salak mangga, salak manggis, salak kerbau, salak penjalin, salak nangka, salak apel, salak pepaya dan salak bukkol. Tahun 2005 salak se nase'atau biasa disebut salak kramat telah dilepas menjadi varietas unggul salak Bangkalan (Sudaryono dkk., 1993).

Buah salak Bangkalan mempunyai kekhasan tersendiri dibandingkan dengan jenis salak lainnya, yaitu memiliki warna daging buah yaitu kuning kecoklatan, rasanya asam, manis sepet, tekstur buah tidak masir, kandungan air lebih banyak, sehingga apabila dikonsumsi akan terasa lebih segar. Jenis salak Bangkalan ini berpotensi untuk dikembangkan menjadi varietas unggul, sehingga mampu menambah perekonomian masyarakat,

Keripik merupakan produk pangan yang berasal dari buah-buahan atau umbi-umbian. Keripik dihasilkan melalui tahapan pengupasan, pengirisan, dan penggorengan. Keripik banyak menyerap minyak selama penggorengan, banyak sedikitnya minyak yang diserap akan mempengaruhi rasa, tekstur, serta penampakan keripik. Keripik merupakan salah satu camilan yang banyak diminati dan difavoritkan oleh hampir seluruh kalangan orang yang ada di Indonesia. Keripik vacum frying merupakan keripik yang digoreng di dalam kondisi ruang tertutup dengan tekanan rendah. Suhu dan lama penggorengan tergantung banyak sedikitnya buah yang digoreng dan karakteristik bahan yang akan digoreng. Penggorengan dengan metode vacuum akan menghasilkan produk pangan dengan kandungan gizi seperti protein, lemak, dan vitamin yang tetap terjaga. Sistem penggorengan seperti ini, produk-produk pangan yang rusak dalam penggorengan akan bisa digoreng dengan baik, menghasilkan produk yang kering dan renyah, tanpa mengalami kerusakan nilai gizi dan flavor seperti halnya yang terjadi pada penggorengan biasa.

Salah satu upaya mempertahankan mutu dan daya simpan buah adalah mengolahnya menjadi makanan kering (keripik buah). Pengolahan buah menjadi keripik perlu dukungan teknologi sehingga kualitas keripik yang dihasilkan dapat diterima konsumen. Salah satu cara untuk menghasilkan makanan sehat tanpa mengubah bentuk aslinya adalah dengan menggunakan teknologi penggorengan vakum (Siregar et al. 2004; Departemen Pertanian 2008).

Mesin penggoreng vakum (vacuum frying) dapat mengolah komoditas peka panas seperti buah-buahan menjadi hasil olahan berupa keripik (chips), seperti keripik nangka, keripik apel, keripik pisang, keripik nenas, keripik melon, keripik salak, dan keripik pepaya. Dibandingkan dengan penggorengan secara konvensional, sistem vakum menghasilkan produk yang jauh lebih baik dari segi penampakan warna, aroma, dan rasa karena relatif seperti buah aslinya (Siregar et al. 2004; Departemen Pertanian 2009; Enggar 2009). 
Beberapa kelebihan keripik jika menggunakan mesin vacuum frying, diantaranya adalah hasil gorengan keripik tidak berubah dari warna aslinya, aroma dan rasanya tidak berubah dari buah maupun sayur yang asli, tidak perlu tambahan rasa, (no perisa, no MSG, hasil gorengan keripik lebih renyah, material bahan mesin aman untuk makanan (food grade), kandungan nutrisi dalam produk tidak hilang, produk hasil mesin ini tidak mudah tengik, jadi lebih awet. Untuk itu pada kegiatan ini dilakukan pembuatan keripik salak Bangkalan dengan menggunakan mesin vacum frying dan mengidentifikasi karakteristik keripik salak yang dihasilkan. Manfaat dari kegiatan ini dapat memberikan informasi teknologi pengolahan keripik salak dan meningkatkan nilai ekonomis salak Bangkalan.

\section{METODE PENGABDIAN MASYARAKAT}

Tempat kegiatan diseminasi proses pembuatan keripik salak Bangkalan dengan teknologi vacuum frying di KWT Ambudi Makmur Morkolak Kramat Bangkalan. Kegiatan ini merupakan bagian dari Program kegiatan pengabdian masyarakat Hi-Link RistekDikti. Kegiatan meliputi: penyuluhan dan pelatihan pembuatan keripik salak Bangkalan sampai benar-benar menghasilkan keripik salak yang baik dengan karakteristik nutrisi dan masa simpan yang sesuai dengan standar keamanan pangan.

Prosedur pembuatan keripik salak meliputi: pengupasan buah salak dari kulitnya dan dipisahkan daging dari bagian bijinya lalu dibelah menjadi 2 bagian. Kemudian buah salak ini dilakukan perendaman pada air selama 10 menit. Salak disimpan didalam freezer selama dua hari. Mesin vacum frying disiapkan dengan penggunaan suhu $85^{\circ} \mathrm{C}$, tekanan 1 atm, dan jumlah minyak goreng yang dipergunakan sebanyak 10 liter. Kemudian Salak digoreng menggunakan mesin vacum frying selama 60 menit dan ditunggu sampai keripik matang serta kadar airnya telah dihisap semua oleh mesin vacum frying. Keripik salak diangkat dan ditiriskan menggunakan Spiner. Keripik salak sudah siap dikemas dapat menggunakan pengemas alumunium foil atau plastik. Kemudian dilakukan pengujian karakteristik fisikokimia pada masa simpan keripik salak. Penyimpanan pada suhu ruang (1 minggu, 2 minggu, 3minggu, 4 minggu, 5 minggu, 6 minggu).

\section{HASIL DAN PEMBAHASAN}

Sejak tahun1996 sejumlah kelompok tani (poktan) di Dusun Murkola, Desa Kramat, Kecamatan Bangkalan, berinovasi membuat penganan berbahan dasar salak. Potensi kebun salak perlu dikembangkan dengan dibangun sebagai kawasan agrowisata. Desa Kramat yang memang terkenal sebagai sentra produk olahan salak di Bangkalan terutama makanan yang dikreasi Poktan Ambudi Makmur.

KWT Ambudi Makmur terdiri dari beberapa warga yang memiliki kebun salak, tidak hanya warga di desa Keramat saja yang tergabung pada anggota ambudi makmur ini tetapi juga di luar desa Keramat. Ibu Saniyah merupakan ketua kelompok yang mengawali dari berjalannya usaha pengolahan salak ini, kolompok tani ambudi makmur mendapatkan pelatihan dan keterampilan untuk mengolah hasil kebun. Dodol dan sirup salak merupakan produk yang pertama kali diproduksi. Akan tetapi, buah salak masih melimpah ruah dan masih berceceran di kebun salak ketika panen raya, akhirnya ide untuk memproduksi varian baru harus dilakukan. Salah satunya dengan membuat produk keripik salak. 
Keripik adalah produk yang dihasilkan melalui tahapan pengupasan, pengirisan, dan penggorengan. Keripik vacum frying merupakan keripik yang digoreng di dalam kondisi ruang tertutup dengan tekanan rendah. Suhu dan lama penggorengan tergantung banyak sedikitnya buah yang digoreng dan karakteristik bahan yang akan digoreng. Penggorengan dengan metode vacuum akan menghasilkan produk pangan dengan kandungan gizi seperti protein, lemak, dan vitamin yang tetap terjaga. Sistem penggorengan seperti ini, produk-produk pangan yang rusak dalam penggorengan akan bisa dijaa dengan baik.

Pada kondisi vakum, suhu penggorengan dapat diturunkan menjadi $70-85^{\circ} \mathrm{C}$ karena penurunan titik didih minyak. Dengan demikian, kerusakan warna, aroma, rasa, dan nutrisi pada produk akibat panas dapat dihindari. Selain itu, kerusakan minyak dan akibat lain yang ditimbulkan karena suhu tinggi dapat diminimalkan karena proses dilakukan pada suhu dan tekanan rendah. Penelitian tentang penggorengan hampa telah dilakukan oleh beberapa peneliti sebelumnya seperti Sudjud (2000), melakukan penelitian utama pada penggorengan hampa udara buah cimpedak terbaik pada pada suhu $90^{\circ} \mathrm{C}$ selama 30 menit. Begitu juga dengan Nurhudaya (2011), diperoleh suhu yang optimal untuk penggorengan hampa durian menjadi keripik durian berdasarkan hasil pembobotan adalah $75^{\circ} \mathrm{C}$ dan 85 menit. Hasil penelitian Paramita (1999) disimpulkan bahwa keripik sawo terbaik diperoleh pada penggorengan hampa dengan suhu $95^{\circ} \mathrm{C}$ dengan waktu 40 menit.

Hasil pengujian kadar air, kadar abu dan kadar lemak keripik salak semakin meningkat dengan semakin lama penyimpanan. Pengemasan menggunakan aluminium foil mengandung kadar air, kadar abu dan kadar lemak yang lebih sedikit daripada keripik yang menggunakan kemasan plastik PVC. Tingginya kadar air, kadar abu dan kadar lemak pada keripik menyebabkan kerusakan keripik salak lebih cepat terjadi. Kerusakan ini dapat berupa keripik sudah tidak lagi renyah dan mulai mengalami ketengikan karena kandungan minyak yang besar menyebabkan mudah teroksidasi dan dipercepat dengan penggunaan kemasan plastik yang transparan sehingga mudah terpapar oleh panas, sinar dan oksigen.

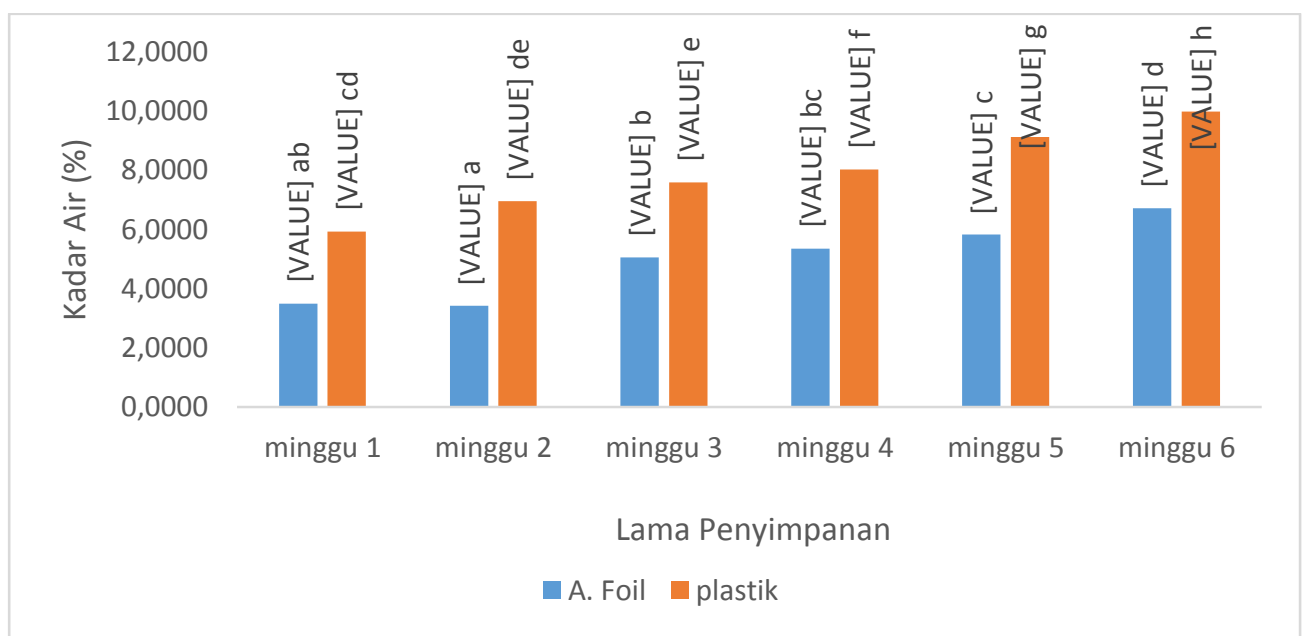

Gambar 1. Kadar air keripik salak dengan kemasan aluminium foil dan plastik selama penyimpanan 

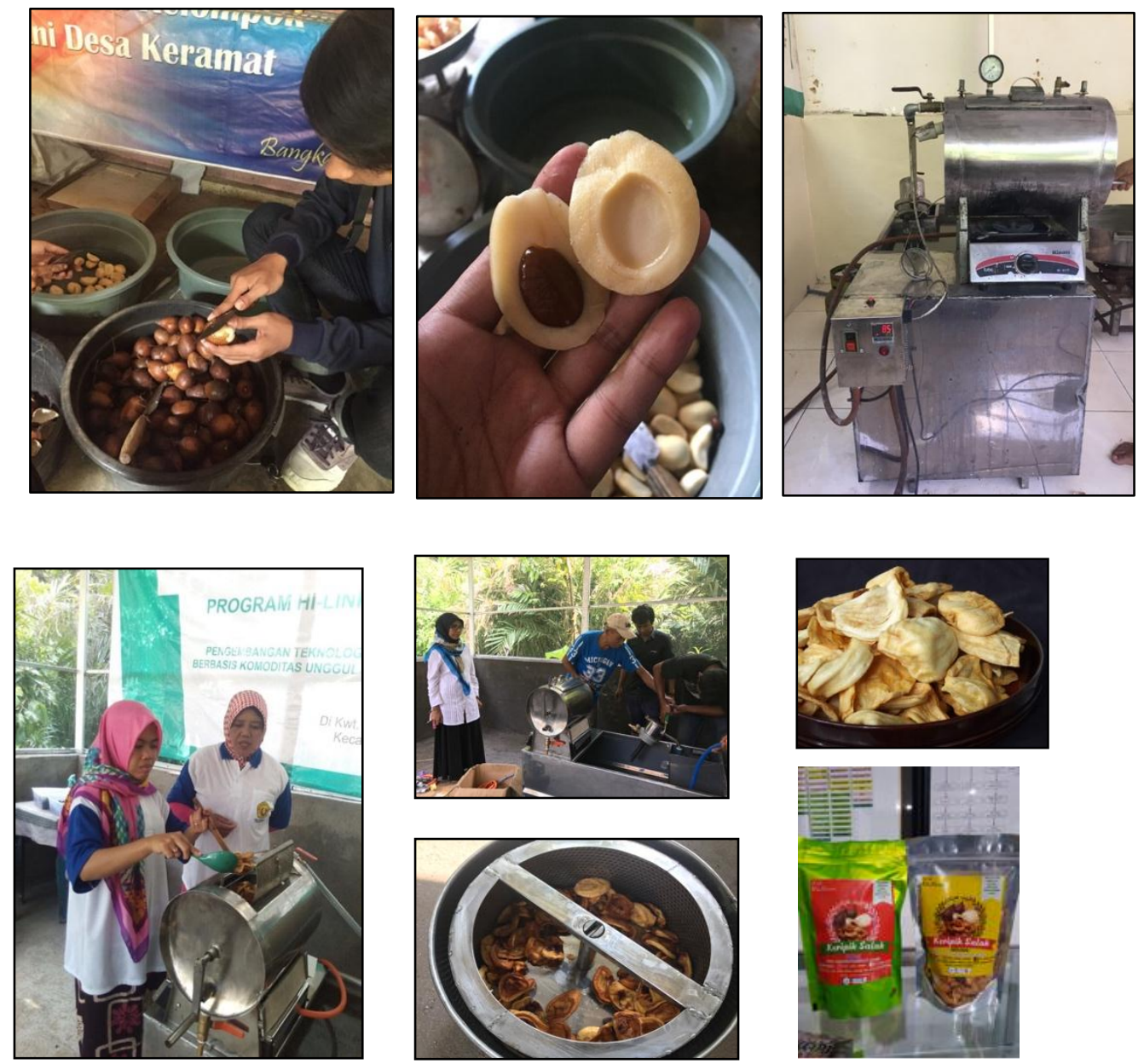

Gambar 2. Proses pembuatan keripik salak dengan mesin vacum frying

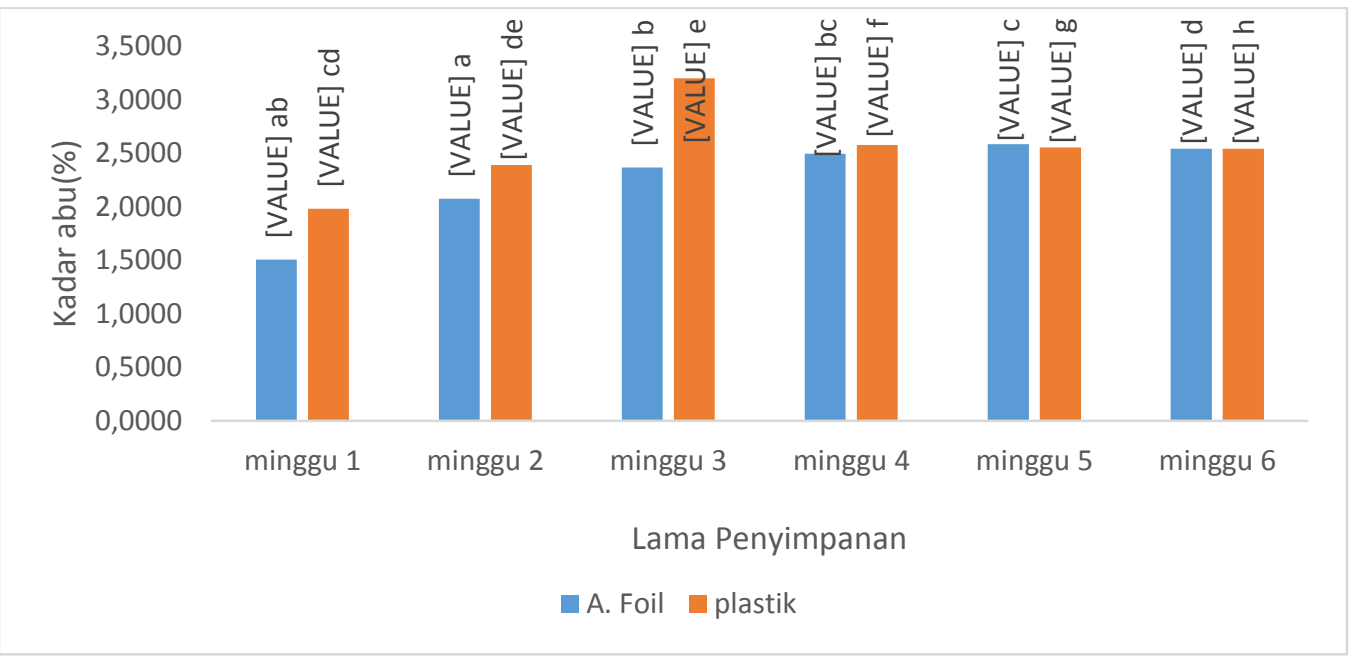

Gambar 3. Kadar abu keripik salak dengan kemasan aluminium foil dan plastik selama penyimpanan 
Kadar air salak segar sebagai bahan baku keripik sebesar rata-rata 78\%, setelah menjadi keripik kadar airnya menjadi 3.4\% - 6.7\% dengan kemasan aluminium foil dan 5.9\% 9.9\% dengan kemasan plastik, sedangkan kandungan kadar abu sebesar $1.5 \%-2.5 \%$ dengan kemasan aluminium foil dan 1.9\%-2.5\% dengan kemasan plastik, kadar lemak keripik dengan kemasan aluminium foil sebesar 11.8\%-19.3\%, 15.4\%-24.1\% dengan kemasan plastik selama penyimpanan sampai 6 minggu. Kandungan kadar air, abu dan lemak pada keripik salak ini baik dengan kemasan aluminium foil maupun dengan kemasan plastin masih memenuhi Standar mutu keripik buah menurut SNI 01-43061996, yaitu kadar air maksimal 22\%, kadar abu maksimal 3\% dan kadar lemak maksimal $25 \%$.

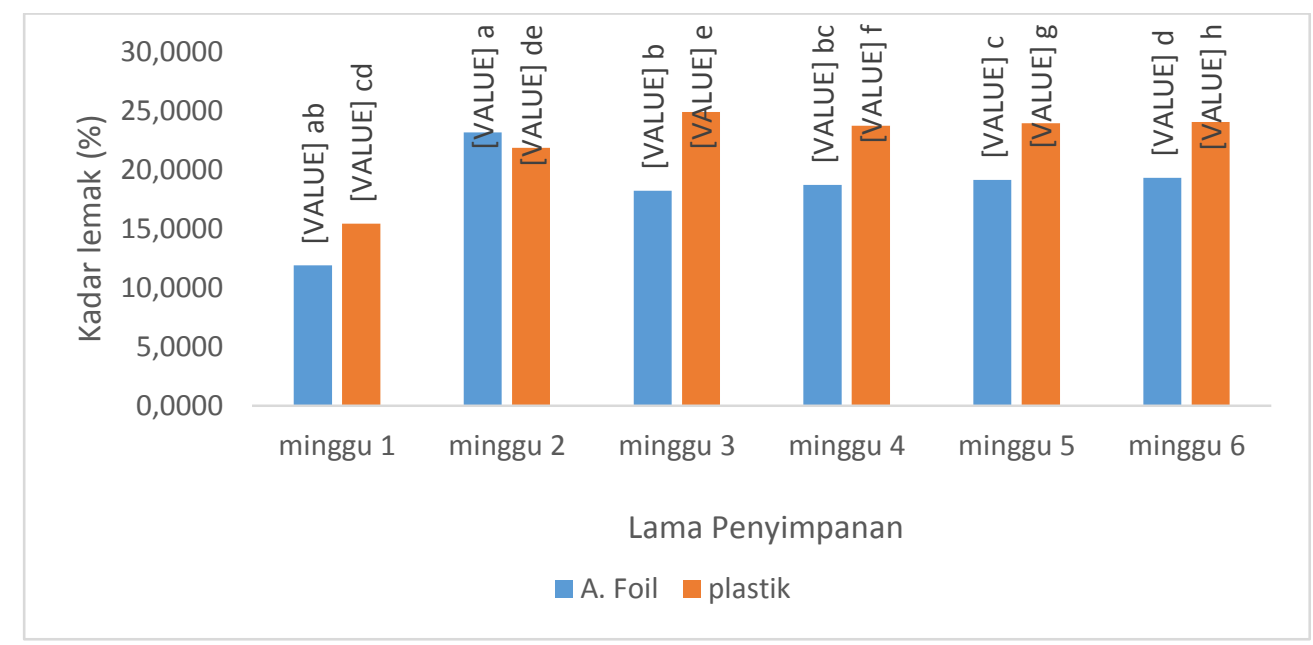

Gambar 4. Kadar lemak keripik salak dengan kemasan aluminium foil dan plastik selama penyimpanan

Kemasan yang digunakan untuk bahan keripik termasuk kemasan yang konvensional seperti plastik PVC dan alumunium foil. Menurut Sulcan dan Endang (2007) Polivinil Klorida dibuat dari monomer yang mngandung gugus vinil. PVC mempunyai sifat kaku, keras, namun jernih dan lengkap, sangat sukar ditembus air dan permeabilitas gasnya rendah. Pemberian plasticizers (biasanya ester aromatik) dapat melunakkan film yang membuatnya lebih fleksibel tetapi regang putusnya rendah, tergantung jumlah plasticizers yang ditambahkan. Alumunium merupakan bahan kemasan yang juga banyak digunakan. Alumunium tidak memiliki ketahanan terhadap oksigen sehingga pada lapisan atas sering dilapisi dengan alumunium oksida, Al2O3. Namun, ada berbagai macam gas, uap dan cairan yang agresif yang dapat merusak lapisan tersebut. Misalnya air kontak dengan logam berat. Keuntungan utama penggunaan alumunium dibandingkan dengan bahan kemasan lain adalah sifat absolut kedap terhadap cahaya dan gas. Kelemahan utama adalah tingginya kebutuhan energi pada saat produksi, dimana telah diupayakan menguranginya dengan menggunakan kembali bahan-bahan kemasan alumunium. Foil adalah bahan kemas dari logam, berupa lembaran alumunium yang padat dan tipis dengan ketebalan kurang dari $0,15 \mathrm{~mm}$. Foil mempunyai sifat thermotis, fleksibel, dan tidak tembus cahaya. Ketebalan dari alumunium foil menentukan sifat protektifnya. Foil dengan ketebalan rendah masih dapat dilalui oleh gas dan uap. Sifat alufo yang tipis dapat diperbaiki dengan member lapisan plastik atau kertas menjadi foil-plastik, foil-kertas, atau kertas-foil-plastik (Syarief et al., 1989) 
Menurut Institute of Food Science and Technology (1974), umur simpan produk pangan adalah selang waktu antara saat produksi hingga konsumsi di mana produk berada dalam kondisi yang memuaskan berdasarkan karakteristik penampakan, rasa, aroma, tekstur, dan nilai gizi. Sementara itu, Floros dan Gnanasekharan (1993) menyatakan bahwa umur simpan adalah waktu yang diperlukan oleh produk pangan dalam kondisi penyimpanan tertentu untuk dapat mencapai tingkatan degradasi mutu tertentu.

Terdapat beberapa faktor yang mempengaruhi penurunan mutu produk pangan. Floros dan Gnanasekharan (1993) menyatakan terdapat enam faktor utama yang mengakibatkan terjadinya penurunan mutu atau kerusakan pada produk pangan, yaitu massa oksigen, uap air, cahaya, mikroorganisme, kompresi atau bantingan, dan bahan kimia toksik atau off flavor. Faktor-faktor tersebut dapat mengakibatkan terjadinya penurunan mutu lebih lanjut, seperti oksidasi lipida, kerusakan vitamin, kerusakan protein, perubahan bau, reaksi pencoklatan, perubahan unsur organoleptik, dan kemungkinan terbentuknya racun.

Menurut Christian (1980) Faktor yang sangat berpengaruh terhadap penurunan mutu produk pangan adalah perubahan kadar air dalam produk. Aktivitas air (aw) berkaitan erat dengan kadar air, yang umumnya digambarkan sebagai kurva isotermis, serta pertumbuhan bakteri, jamur dan mikroba lainnya. Makin tinggi aw pada umumnya makin banyak bakteri yang dapat tumbuh, sementara jamur tidak menyukai aw yang tinggi. Mikroorganisme menghendaki aw minimum agar dapat tumbuh dengan baik, yaitu untuk bakteri 0,90, kamir 0,80-0,90, dan kapang 0,60-0,70. Prabhakar dan Amia (1978) menyatakan, pada aw yang tinggi, oksidasi lemak berlangsung lebih cepat dibanding pada aw rendah. Kandungan air dalam bahan pangan, selain mempengaruhi terjadinya perubahan kimia juga ikut menentukan kandungan mikroba pada pangan

\section{PENUTUP}

Keripik salak dengan teknologi vacuum frying menghasilkan keripik dengan karakteristik tekstur yang renyah, dan warna cerah. Penggunaan kemasan keripik salak lebih baik menggunakan kemasan aluminium foil daripada kemasan plastic. Selama penyimpanan sampai 6 bulan menghasilkan kandungan maksimal air (9.9\%), abu (2.5\%) dan lemak (24.1\%) masih memenuhi standar mutu SNI.

\section{UCAPAN TERIMA KASIH}

Ucapan terima kasih kami sampaikan pada Kementerian RISTEKDIKTI yang telah memberikan pendanaan pada Program kegiatan Pengabdian Masyarakat ini melalui Program Hi-Link yang bekerjasama dengan Dinas Ketahanan Pangan-Bappeda Bangkalan serta kepada LPPM UPN Veteran Jawa Timur yang telah banyak memfasilitasi kegiatan ini. 


\section{DAFTAR PUSTAKA}

Badan Standardisasi Nasional.SNI 01-4306-1996

Christian, J.H.B. 1980. "Reduced water activity”. p. 79-90. In J.H. Silliker, R.P. Elliot, A.C. Baird-Parker, F.L. Brian, J.H.B. Christian, D.S. Clark, J.C. Olson Jr., and T.A. Roberts (Eds.). Microbial Ecology of Foods. Academic Press, New York.

Enggar, E.2009.Vacum Fried Snack. [9 September 2009].

Floros, J.D. and V. Gnanasekharan. 1993. Shelf Life Prediction of Packaged Foods: Chemicals, Biological, Physical, And Nutritional Aspects. G. Chlaralambous (Ed.). Elsevier Publ., London.

Institute of Food Science and Technology. 1974. Shelf Life of Food. J. Food Sci. 39: $861-865$

Nurhudaya. 2011. Rekayasa Penggorengan Vakum dan Pengemasan Keripik Durian Mentawai. Skripisi Fakultas Teknologi Pertanian, IPB, Bogor

Paramita ND. 1999. Pengaruh Suhu dan Waktu Penggorengan Hampa (Vacuum Frying) Terhadap Sifat Fisik dan Organoleptik Keripik Sawo (Achras Sapota, L.). Skripisi Fakultas Teknologi Pertanian, IPB, Bogor

Prabhakar, J.V. and B.L. Amia. 1978. Influence of Water Activity on The Information on Monocarbonyl Compounds in Oxidizing Walnut Oil. J. Food Sci. 43: $1.839-1.843$.

Siregar, H.P., D.D. Hidayat, dan Sudirman. 2004. Evaluasi Unit Proses Vacuum Frying Skala Industri Kecil dan Menengah. hlm. I-4-1 s.d. I-4-5.

Sudaryono, T., S, Purnomo dan M. Soleh. 1993. Distribusi Varietas dan Prakiraan Wilayah Pengembangan Salak. Penel. Hort. 5(2): 1-14.

Sudjud HR. 2000. Mempelajari Pengaruh Suhu dan Waktu Penggorengan Hampa Terhadap Sifat Fisik dan Organoleptik Keripik Buah Cempedak (Artocarpus Integer (Thunb) Merr). Skripisi Fakultas Teknologi Pertanian, IPB, Bogor

Sulcan M dan Endang N W.2007. Keamanan Kemasan Plastik dan Styrofoam. Semarang

Syarief, R., S. Santausa dan S.B. Isyana 1989. Buku dan Monograf Teknologi Pengemasan Pangan. PAU. IPB, Bogor 